\title{
Economic Benefits of Supplemental Irrigation in Uganda
}

\author{
Fahad Kimera1, Hani Sewilam ${ }^{1,2 *}$, Emad Imam ${ }^{3}$ \\ ${ }^{1}$ Center for Sustainable Development, The American University in Cairo, Cairo, Egypt \\ ${ }^{2}$ Department of Engineering Hydrology, The RWTH Aachen University, Aachen, Germany \\ ${ }^{3}$ Department of Irrigation, Cairo University, Cairo, Egypt \\ Email: fkim@aucegypt.edu, *sewilam@lfi.rwth-aachen.de, eimam@aucegypt.edu
}

How to cite this paper: Kimera, F., Sewilam, H. and Imam, E. (2018) Economic Benefits of Supplemental Irrigation in Uganda. Agricultural Sciences, 9, 1401-1418. https://doi.org/10.4236/as.2018.911097

Received: September 6, 2018

Accepted: November 10, 2018

Published: November 13, 2018

Copyright $\odot 2018$ by authors and Scientific Research Publishing Inc. This work is licensed under the Creative Commons Attribution International License (CC BY 4.0).

http://creativecommons.org/licenses/by/4.0/ (c) (i) Open Access

\begin{abstract}
Rainfall variability and the recurrent droughts in the semi-arid regions of Sub-Saharan Africa have far reaching consequences. They have major effects on the socio-economic and environmental sustainability of rural communities. This study investigates the technical, economic, and financial feasibility of small-scale rain water harvesting, and supplemental irrigation (RWHSI) system to mitigate the negative impact of long droughts on crop production. The proposed system consists of limited farm grading to direct the harvested rain water to a lined earth-pond where several alternatives for pumping are proposed for supplemental irrigation schemes. The proposed scheme is mainly activated during the short period when the soil moisture is most critical for the crop yield. To reach an optimum size of the pond, the soil moisture during the critical growth period is simulated using FAO's water productivity model (AquaCrop). The pond size is optimized by applying AquaCrop for several years with the actual rainfall pattern and the possible supplemental irrigation applications. For each year with its possible drought periods, crop yield for each pond size is predicted, then used for the economic feasibility of the pond sizes. The optimum pond size is the one maximizing its benefit over its cost. The feasibility of the proposed RWHSI is investigated on maize production for the Soroti area in Uganda. For the rainfall pattern, soil conditions, and maize growth characteristics of Soroti, the proposed RWHSI is proved by simulations to be technically, and economically feasible. For a typical farm holding with a catchment area of one hectare, an 800 cubic-meters lined earth-pond can give up to $50 \%$ increase in the maize yield. After considering the construction and running costs of the supplemental irrigation system, the pay-back period is 6 years. The required investment cost for this RWHSI is low, and likely to be within the financial capacity of many farmers, while their
\end{abstract}


selection of the pumping system will depend on their manpower and financial ability.

\section{Keywords}

Runoff Harvesting, Rain-Fed Irrigation, Rainwater Harvesting, Sub-Saharan Africa, Drought Mitigation

\section{Introduction}

Agricultural production accounts to almost $70 \%$ of the global fresh water extractions [1]. Meanwhile water is considered an essential element in both socio-economic and environmental development [2] [3] [4]. Pramod et al. and Rockstrom et al. [5] [6], reported that by 2050, the world will need an additional $5000 \mathrm{~km}^{3} /$ year of water for sustenance to meet the increasing food demands due to population explosion. Different researchers have suggested that supplemental irrigation to rain-fed agricultural settings could be a potential solution to the increasing food demands [1] [2]. A study conducted by Falkenmark et al. [7] reported that an approximate $80 \%$ of the world's cultivable land depends on rainfall. Yet rain-fed production produces up to $70 \%$ of the global food supply. However, there is a significant change in rainfall patterns, intensities and distribution [8]. The Food and Agriculture Organization (FAO) reported that almost three quarters of the fresh water resources in Sub-Saharan Africa (SSA) are used for agricultural purposes [9]. Estimates show that uncertain weather conditions as well as insufficient water for irrigation could cause the agricultural productivity in several countries to fall by up to $50 \%$ over the next decade, severely affecting their prospects of greater social and economic development [10]. FAO further reported that in SSA, there is an approximate 42 Million hectares of land that require irrigation [11]. Statistics have shown that $63 \%$ of Sub-Saharan population resides in rural areas and relies on rain-fed agriculture [12]. Almost $94 \%$ of agricultural land south of the Sahara Desert depends on rainfall for crop production [5] [13].

Agriculture, a main contributor to Uganda's economy made up almost a quarter of the gross domestic product (GDP) in 2013 [14]. The agricultural sector employs more than half of the country's population in addition to providing a foundation for the development of other economic spheres [15]. However, moisture stress to crops in Uganda has become the biggest challenge in the agricultural industry. Ronald Kalali an agricultural officer at Mobuku government prison, reported how drought drove their 300 acres of land to zero yields. "We were going to utilize all the rains because we planted in time but unfortunately we stopped receiving rains in March immediately after we had planted. We are expecting zero yields," [16]. When rainfall is small, not enough to support the full growth of a crop, full irrigation schemes are usually considered depending 
on streams or ground water resources. However, surface water resources may require large storage facilities such as dams and reservoirs to store water from the rainy to the dry season. Such facilities require high capital investments which reduce benefits from production and as well pose a great environmental concern. These findings were presented by McCartney \& Smakhtin [17] who reported that large water reservoirs have negative social-environmental and economic constraint. They occupy large surface area reducing the area under crop production, causes environmental degradation, distortion of the soil structure and underground water movement hence leading to disastrous natural disasters like floods, earthquakes and drought [18].

On the other hand, when the annual rainfall is large, but its pattern includes several inter-seasonal droughts, crops are then subject to severe loss. This becomes worse if the drought is long and coincides with the period that critically affects the growth of the cultivated crop [19]. Supplemental irrigation could be the most effective solution to mitigate the negative effects of long droughts. Supplemental irrigation (SI) is defined as the application of limited amounts of water during critical crop growth stages to essentially rain-fed crops to improve and stabilize yields by maintaining a minimum amount of soil moisture in the root zone [20]. Even though SI is thought of as an effective and promising practice to mitigate drought effects, the system faces several challenges which may include:

- The difficulty to accurately plan the timing and amount of water to be applied to crops in advance.

- SI does not require a fixed schedule as it is with a full irrigation system since the system is dependent on rainfall variability.

- The practicability of storing and retaining water most especially precipitation till the when it is needed by crops despite of the huge seepage and evaporation losses [21].

This study attempts to investigate the possible solutions to such challenges most especially with the small-scale farming systems in the rain-fed agricultural zones. Findings from Pandey et al. [22] reported a higher increment in crop yields by developing smaller sized ponds for dry spell mitigation. Despite the many conducted studies on runoff harvesting, there are few published data specifically for supplemental irrigation of maize crops which happens to be the staple food for most of the sub-Saharan African countries [5]. Generally, there are has been lack of scientific consensus about both the trend and distribution of rainfall in developing countries. Kansiime et al. and McSweeeney et al. [23] [24] reported a $4.7 \%$ decrease per decade in rainfall over the past fifty years in Uganda. Geerts and Raes; Mango et al.; Vohland and Barry [25] [26] [27] previously reported that crop failures can be caused by short term agricultural droughts which can occur for just a few days and the yields can be greatly reduced. Findings from the United Nations Population Fund in collaboration with the Ugandan government [28] [29] reported an average yield reduction of $50 \%$ in maize 
during the growing seasons of 2006 and 2008 caused by long droughts. In many rain-fed agricultural zones, low crop yields are attributed due to low soil moisture, inappropriate management of soil and other poor field practices. Shortage of soil moisture due to drought and dry spells especially during the critical crop growth stages (flowering and grain filling) can lead to severe losses of crop harvests.

This research aims at increasing crop productivity through reducing crop failures during the moisture-critical growth stages. At a greater extent, these failures are due to low soil moisture content. This can be achieved by having an effective supplemental irrigation system that can easily be adopted and sustained by a small-scale farmer. The principle objective of this study is to develop a supplemental irrigation scheme for maize production under rain-fed agriculture. The study proposes a supplemental irrigation scheme that focuses on harvesting surface runoff during the intensive rainfall events and uses the stored water during the periods of water shortage in the growing season. The proposed scheme relies completely on rainfall. The study also employs FAO's water productivity model (Aquacrop) to simulate for the economic benefits of both rain-fed and supplemental irrigation system under crop production. The model is simulated using data from a study area in Soroti, Uganda. The simulated benefits along with the costs of establishing the scheme are used to make an economic analysis based on both the model results and the quantitative data that was collected in the study area.

\section{Materials and Methods}

\subsection{Study Area and Data Description}

Soroti is located in Eastern Uganda between geographical coordinates of $1.541^{\circ}$ to $2.029^{\circ}$ North and $33.39^{\circ}$ to $38.82^{\circ}$ East with an average elevation of $1125 \mathrm{~m}$ above MSL (Figure 1). Annual rainfall averages $1100-1200 \mathrm{~mm}$ distributed between two seasons of March to May (MAM) and September to November (SON) [30]. October to late February or early March and mid-June to late July are traditionally dry seasons for crop harvesting and land preparations. The MAM season is the main growing season however it has become variable with frequent dry spells causing famine [31]. Soroti area lies in the famous low-lying cattle corridor of Uganda. The cattle corridor is the most drought vulnerable region of the country [24] [31]. Rainfall trends over the past 25 years have shown a gradual decline. It's for example evident that regions practicing crop cultivation have had an average decline of around $8 \%$ when rainfall amounts between two periods, 1920 to 1969 and 2000 to 2009 are compared [32] [33]. Climatic data including daily temperature, daily rainfall and solar radiation was collected from the Uganda National Meteorological center in Kampala. Soil samples in addition to both primary and secondary data about the maize cropping system were taken from the study area in Soroti. 


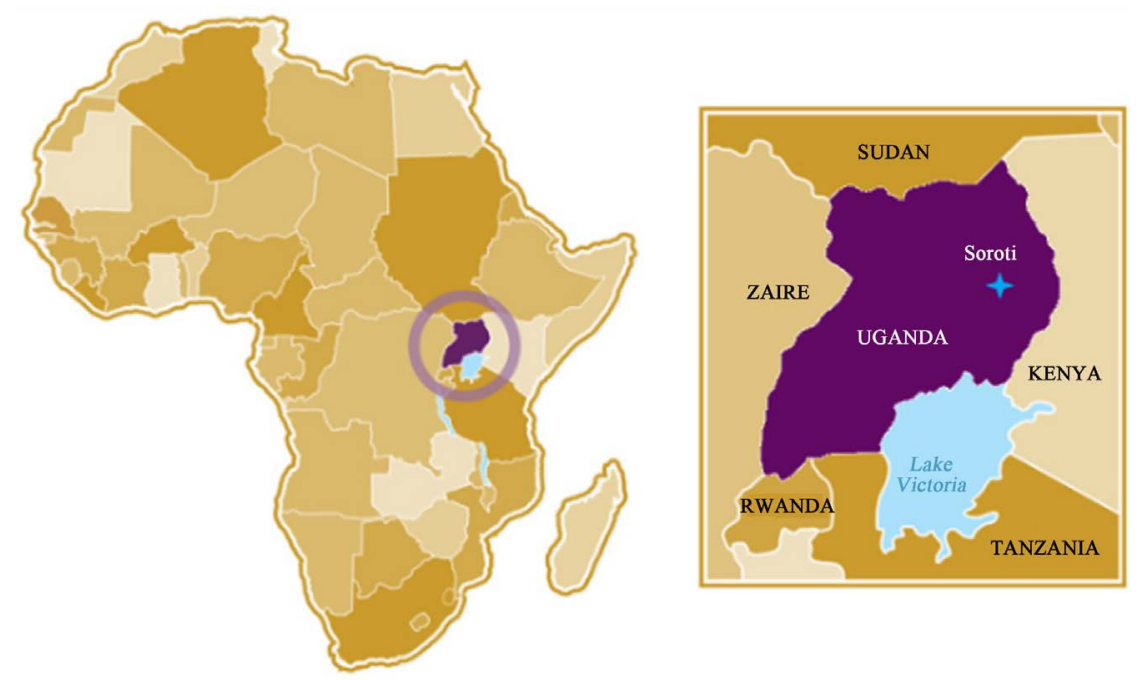

Figure 1. Map showing Soroti-The study area in Eastern Uganda.

Soil samples were taken from three sub-counties in Soroti district i.e. Ogweri, Arapai and Assuret in February 2017 and tested in the lab for their chemical and physical properties. This was a period just before the crops were actively growing and prior to manure applications. The samples were taken from 5 different sites whose soil types have been classified by [34] [35] as shown in Figure 2. Most of the soil in the study area is classified as plinthosols which are characterized by the presence of iron and aluminium oxides giving it more of a red colour [36]. These soils are very shallow and they often form hardpans with repeated wetting and drying which eventually lead to erosion [37].

The analysed samples were collected from the upper soil horizons $(0-30 \mathrm{~cm})$ and in the subsoil layers $(30 \mathrm{~cm}$ to $60 \mathrm{~cm}$ ) from each site under different soil types in the area. The soil physical and chemical characteristics were obtained from both field surveys and laboratory analysis. The soil samples were air-dried, pounded and sieved through $2 \mathrm{~mm}$ sieve to remove any debris then subjected to physical and chemical analysis following standard methods described by Okalebo et al. [38] for routine analysis. Soil $\mathrm{pH}$ was measured in a soil water solution ratio of 1:2.5; Organic matter by potassium dichromate wet acid oxidation method; total Nitrogen determined by Kjeldhal digestion; exchangeable bases from an ammonium acetate extract by flame photometry $\left(\mathrm{K}^{+}, \mathrm{Na}^{+}\right)$and atomic absorption spectrophotometer $\left(\mathrm{Ca}^{2+}, \mathrm{Mg}^{2+}\right)$; and particle size distribution (texture) using the Bouyoucos (hydrometer) method [38]. Also, through continuous field visits, farm observations and consultation from the local farmers, the level of erosion hazard was classified and ranked into three at each sampling position (slight, average and high). Most of these parameters were required to run simulations for the AquaCrop model that is applied in this study (Table 1).

\subsection{Proposed Supplemental Irrigation Concept}

The system is developed to store water and use it for supplemental irrigation 


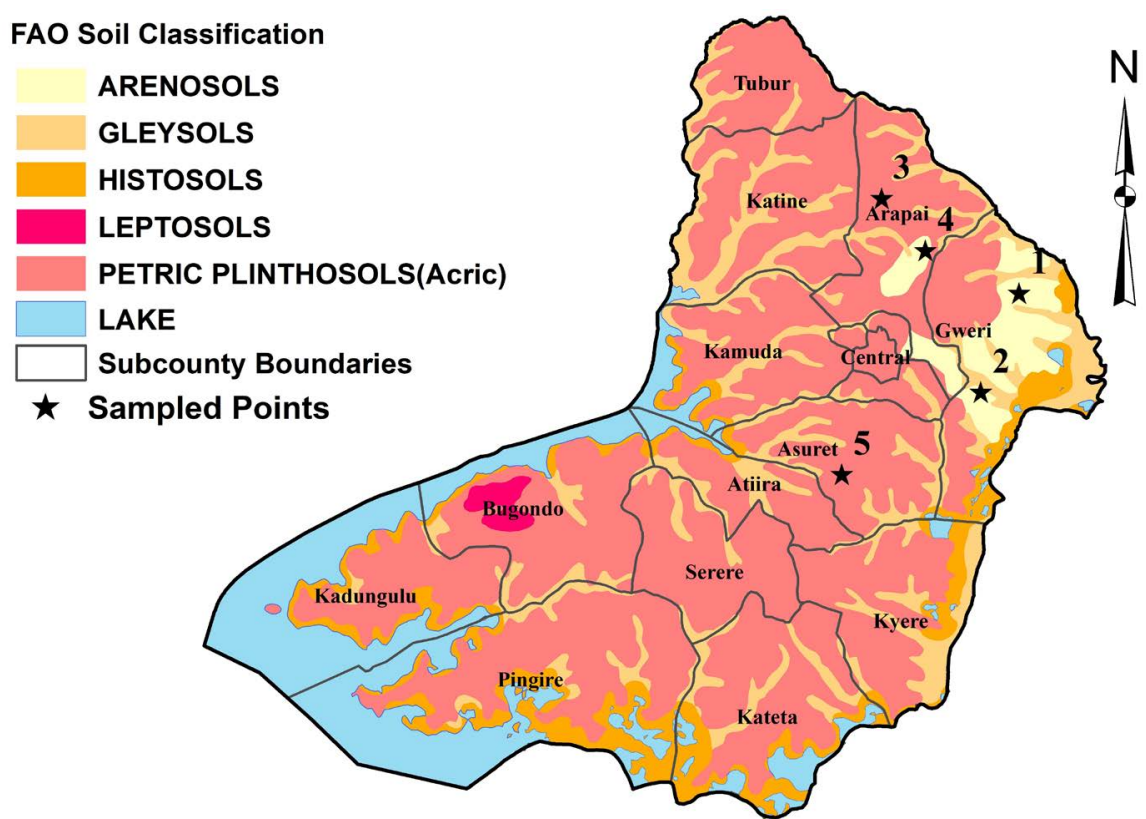

Figure 2. Soils types in Soroti district under FAO classification adopted from Atta-Krah et al. [34].

Table 1. Summary of the site characteristics of the studied soil.

\begin{tabular}{ccccccccc}
\hline $\begin{array}{c}\text { Profile } \\
\text { pits }\end{array}$ & Latitude & Longitude & Slope \% & $\begin{array}{c}\text { Altitude } \\
(\mathrm{mm})\end{array}$ & $\begin{array}{c}\text { Depth } \\
(\mathrm{cm})\end{array}$ & Drainage & $\begin{array}{c}\text { Erosion } \\
\text { Hazard }\end{array}$ & $\begin{array}{c}\text { Surface } \\
\text { Stoniness }\end{array}$ \\
\hline 1 & 1.7782 & 33.7379 & $1-3$ & 1037 & 90.0 & Poorly drained & Average & Nil \\
2 & 1.6777 & 33.6185 & $1-3$ & 1035 & 70.0 & Poorly drained & Average & Nil \\
3 & 1.8620 & 33.6183 & $1-4$ & 1035 & 90.0 & Well drained & Slight & Nil \\
4 & 1.8050 & 33.6515 & $2-5$ & 1038 & 80.0 & Well drained & Slight & Nil \\
5 & 1.6120 & 3357640 & $2-5$ & 1038 & 80.0 & Well drained & Slight & Nil \\
\hline
\end{tabular}

during the most critical water sensitive stages of a maize crop. Irrigation is targeted primarily to be applied during the flowering and grain filling stages. Figure 3 illustrates the concept of supplemental irrigation proposed in this study. When a rainfall event occurs, runoff water flows to the lower areas of the catchment by the effect of gravity. This runoff can be directed at certain points into a water storage pond with the aid of gullies, furrows or rills. The storage medium is composed of the sedimentation pond and a bigger water storage pond with a spill away channel in case of excessive storage. The sedimentation pond is mainly for the settling of sand, trash and other suspended materials from the runoff. Between the sedimentation and the storage pond is an underground inlet pipe that allows water into the storage pond. The bigger storage pond is well lined with a Polyvinyl chloride (PVC) to prevent the heavy losses of water through seepage. Furthermore, the extended part of the liner on the top sides of the pond is covered with a heap of soil to prevent direct contact of the liner with radiation from the sun. 


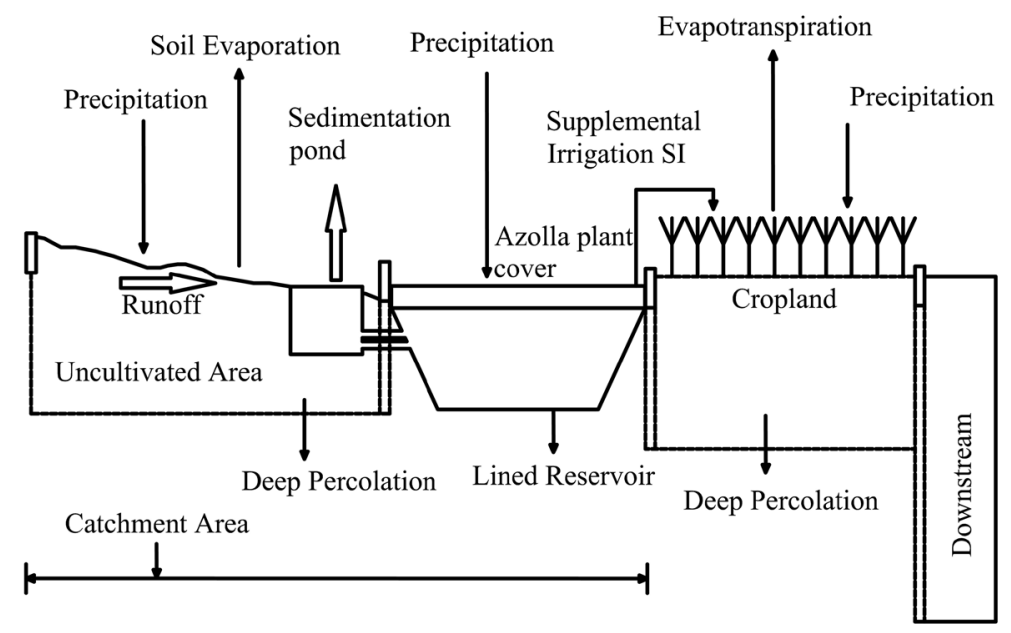

Figure 3. Supplemental irrigation system adopted and modified after pandey et al. [45].

The system also comprise of a surface water floating plant-Azolla as water cover primarily to control mosquito breeding on the surface of the pond [39]. Different authors have reported the great significance of Azolla in controlling mosquito breeding over water surfaces. Azolla mat suppresses mosquito breeding by inhibiting ovi-positioning of the female mosquitoes. It acts as a physical barrier for mosquitoes to lay their eggs on the surface of water [40] [41] [42]. The fern is a multi-purpose plant. It is a great source of proteins to livestock including cows, sheep, pigs and chicken. Azolla can replace conventional chicken meals with $5 \%-15 \%$ and it is also used to control evaporation losses from surface water bodies [43] [44]. From the storage pond, water can be pumped using different alternatives of water lifting techniques to the cropped area. The examined techniques in this study include the traditional rope and bucket system, the treadle or pedal pump, diesel pump and the solar pump. In case of any pump, it should be a submersible pump since the water surface is covered with Azolla plant. The storage pond is established with a total depth of $2 \mathrm{~m}$ with a slope of 1:1.

The system is suitable for the land use in the study area in addition to other areas with similar climatic conditions in Africa facing the same water shortage in agricultural production. This system can easily be constructed and afforded by an average farmer. The simply designed pond is developed to collect water that can serve and feed an average cultivated area of about 3 acres of land for supplemental irrigation. The pond can be designed with varying capacities for water storage.

\subsection{Irrigation and Crop Growth Modelling}

The FAO water productivity model-AquaCrop is used in this study to identify the necessary supplemental irrigation and avoid the losses in the Maize production during the dry spell. AquaCrop simulates the crop growth phases, soil water in the plant root zone and assess crop yield response. The model is used to si- 
mulate maize crop production under the conditions of rain-fed and supplemental irrigation. To run the simulations, the model requires both climatic and soil data as identified in section (2.1). Input data for the simulations was collected, validated and analyzed using the model and then the model results are used to develop a cost benefit analysis. The model functions by relating the interaction between the crop parameters, climatic conditions and the soil properties in addition to the practices of field management [46].

The first simulations were based on the existing farming practices in the study area which is rain-fed agriculture without considering any kind of supplemental irrigation. Crop yields are simulated depending on the soil characteristics, field practices and rainfall. A period of ten years from 2003-2012 is simulated and the crop yields were estimated. Then several simulations were conducted to test for optimization among the four alternative storage pond volumes for a hectare cropland i.e. 1000, 800, 600 and $400 \mathrm{~m}^{3}$. Simulation of maize yields from the model under different irrigation levels are studied and analyzed to develop a cost benefit analysis. The results from the cost benefit are used to recommend the best irrigation system and pond size suitable for the study area. A supplemental irrigation system is established with a simple designed water collecting and storage facility to accommodate surface runoff for the periods of intensive rain events.

\section{Results and Analysis}

\subsection{Rainfall Harvesting and Yield Increase}

Results from the simulation without irrigation show that there is no clear trend of yields since 2003 till 2012. However, the yields only increased with an increase in the amount of rainfall received during the growing season as shown in Table 2. ET refers to the Evapotranspiration measured in $\mathrm{kg}$ yield $/ \mathrm{m}^{3}$; Potential yield is the maximum yield a crop can attain. The actual yield is the green biomass yield while the Dry yield is the harvested crop yields (grains in ton/ha).

Table 2. Rain-fed production analysis for the growing season (March-May).

\begin{tabular}{cccccc}
\hline Season & $\begin{array}{c}\text { Seasonal Rainfall } \\
(\mathrm{mm})\end{array}$ & $\begin{array}{c}\text { ET } \\
\left(\mathrm{kg} \text { yield } / \mathrm{m}^{3}\right)\end{array}$ & $\begin{array}{c}\text { Potential Yield } \\
(\text { ton/ha })\end{array}$ & $\begin{array}{c}\text { Actual Yield } \\
\text { (ton/ha })\end{array}$ & $\begin{array}{c}\text { Dry Yield } \\
(\text { ton/ha })\end{array}$ \\
\hline 2003 & 795 & 1.42 & 13.67 & 13.3 & 6.808 \\
2004 & 426 & 1.16 & 13.7 & 8.6 & 4.285 \\
2005 & 608 & 1.38 & 13.8 & 12.2 & 5.986 \\
2006 & 423 & 1.14 & 13.8 & 9.0 & 4.061 \\
2007 & 510 & 1.56 & 13.9 & 11.7 & 6.321 \\
2008 & 409 & 1.01 & 13.9 & 7.1 & 3.389 \\
2009 & 360 & 1.13 & 14.0 & 7.9 & 3.915 \\
2010 & 628 & 1.53 & 14.0 & 14.0 & 7.022 \\
2011 & 423 & 1.47 & 14.1 & 12.6 & 6.252 \\
2012 & 647 & 1.34 & 14.2 & 11.8 & 5.692 \\
\hline
\end{tabular}


Figure 4 represents the Net irrigation water needs for maize analyzed for ten years using the model. The upper line graph shows the Net supplemental irrigation water needs (demand) to keep the soil moisture between the threshold for leaf expansion and the threshold for stomata closure i.e. at 75\% Readily Available Water (RAW). The maximum values for net irrigation water needs are observed with years that had low amounts of rainfall during the seasons 2004, 2006, 2008 and 2009. The lower line graph represents the potential annual runoff (supply) that can be collected over a catchment area of one hectare calculated using the model. Although the study area is characterized with two growing seasons annually, MAM and SON, maize is always planted in the first season (MAM) which is most vulnerable to drought and it is the season that was simulated. Maize in most cases is intercropped with other crops such as soybean and groundnuts. Notably, such a diversified cropping pattern could lead to significant losses in yields in case of a drought within the growing season. For this reason, we assumed in this study that the annual water storage will only be used during this particular season alone for only one crop per year.

Setting the soil moisture level at 75\% RAW creates limited tension or stress to the crop whereby it directs most of its available water needs to grain formation. This moderate level of water stress in the soil root zone induces more grain formation in many cereal crops. Regardless of having such a low moisture level with minimal stress to the crops, the net irrigation water demand is considerably still high compared to the potential annual runoff that can be collected. For this reason, the proposed supplemental system specifically applies irrigation water in only the critical growth stages of maize. So, unless the catchment area is bigger than one hectare, there is need for additional irrigation water supply e.g. underground water pumping or stream diversion.

Figure 5 compares three different scenarios i.e. the average seasonal maize water needs for the study area which is set at $580 \mathrm{~mm}$, supplemental irrigation using surface runoff and the total seasonal rainfall received over the study area for each season. The values per unit area are calculated using the model. These

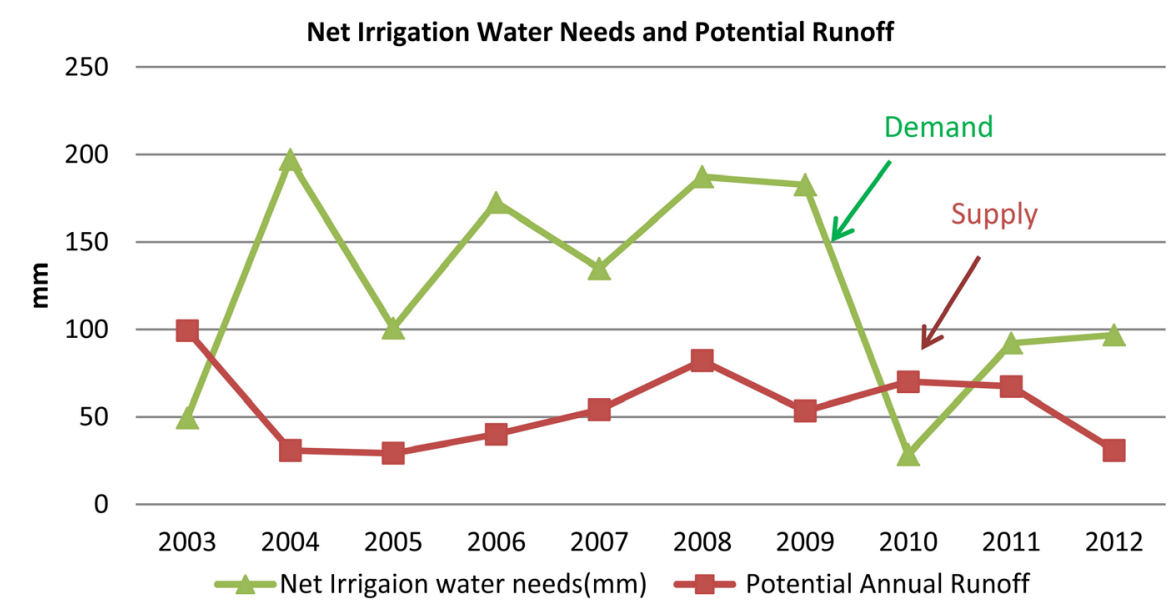

Figure 4. Irrigation demand vs. potential supply. 


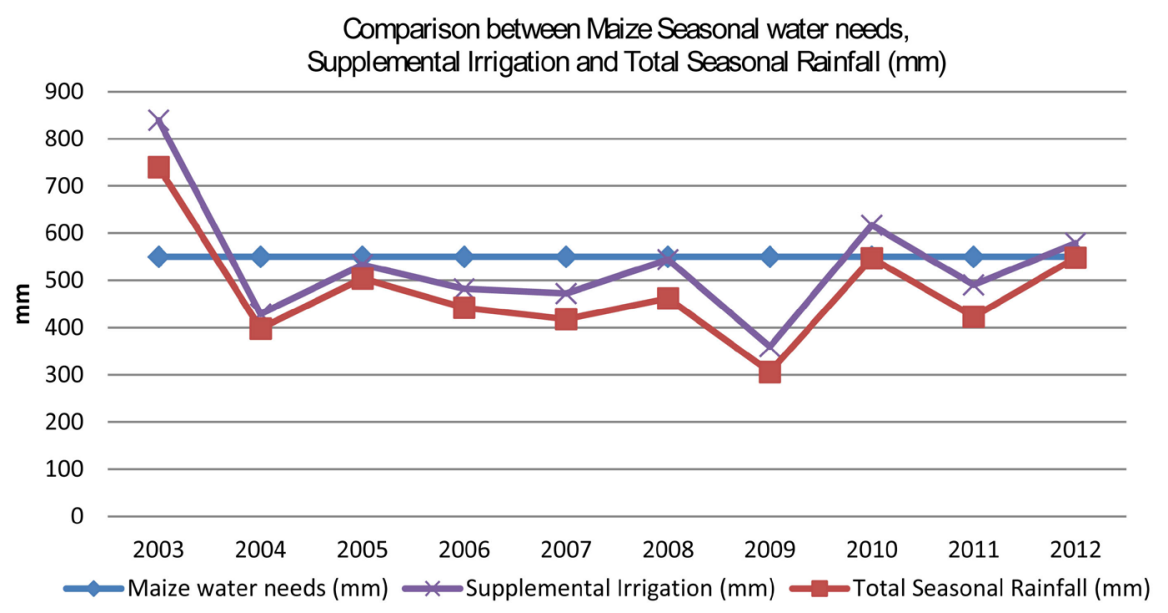

Figure 5. Reducing the Irrigation water gap.

results explain the significance of supplemental irrigation using runoff water as to reduce the water gap between what is needed and what is supplied as rainfall. Maize crops require an average seasonal water needs between $500-800 \mathrm{~mm}$ depending on the cultivar of the crop, soil characteristics and climatic condition [47]. In our case, the average seasonal rainfall received for the period of 10 years was even below $500 \mathrm{~mm}$.

In a way to cope with the water shortage in rain-fed agriculture, Figure 5 presents a simple economic solution of how the water gap in maize production can be reduced. Applying such a supplemental irrigation scheme specifically in the critical stages can reduce the moisture water demands by more than $50 \%$ and greatly increase crop yields. The maize seasonal water needs in the study area is set to be constant at $580 \mathrm{~mm}$ for all the growing seasons. It is observed that applying supplemental irrigation actually provides close to the needed seasonal water needs required by the maize crop to flourish and produce good yields.

The study found that the maximum amount of runoff that can be collected from a hectare catchment is $100 \mathrm{~mm}$ and the minimum at about $40 \mathrm{~mm}$. With these values, different alternative pond volumes are proposed to collect the all year around runoff for supplemental irrigation of maize for the critical stages. The pond capacities that are examined in this study are 1000, 800, 600 and 400 $\mathrm{m}^{3}$ pond volumes. Figure 6 shows the total yields in ton/ha with Rain-fed system and Supplemental Furrow Irrigation using different pond volumes over the critical growth stages of maize crops under a one-hectare land. Both the 800 and $1000 \mathrm{~m}^{3}$ had relatively similar crop yields with supplemental irrigation. This means that large reservoirs do not necessarily increase per capita income from maize production under one-hectare cropland in particular.

\subsection{Economic Feasibility of Supplemental Irrigation}

A cost-benefit analysis of the four capacities $\left(1000,800,600\right.$ and $\left.400 \mathrm{~m}^{3}\right)$ has been carried out. Table 3 gives an account of the costs of the construction of the 


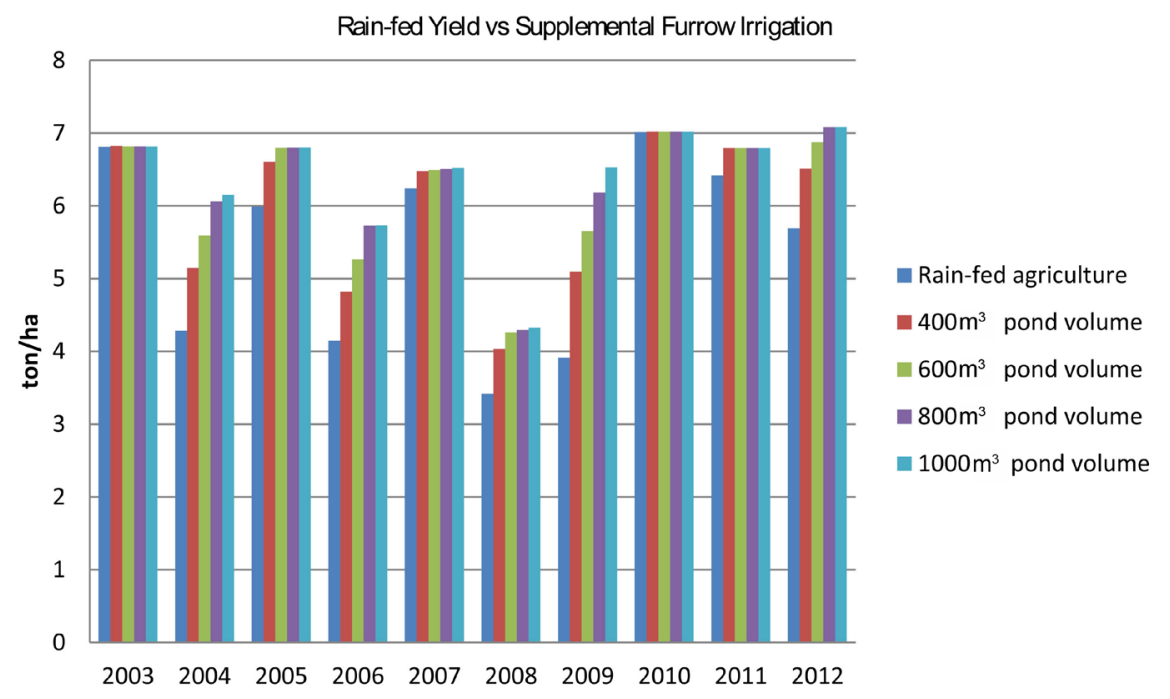

Figure 6. Rain-fed Yield (ton/ha) vs. supplemental furrow irrigation.

Table 3. Pond dimensions and construction costs.

\begin{tabular}{ccccccc}
\hline $\begin{array}{c}\text { Pond } \\
\text { Volume } \\
\left(\mathrm{m}^{3}\right)\end{array}$ & $\begin{array}{c}\text { Pond } \\
\text { Dimensions } \\
(\mathrm{m})\end{array}$ & $\begin{array}{c}\text { Pond Liner } \\
\text { Dimensions } \\
(\mathrm{m})\end{array}$ & $\begin{array}{c}\text { Unit Cost of } \\
\text { Pond Liner } \\
(U G X)\end{array}$ & $\begin{array}{c}\text { Total Cost of } \\
\text { Pond Liner } \\
(U G X)\end{array}$ & $\begin{array}{c}\text { Total } \\
\text { Construction } \\
\text { Costs }(U G X)\end{array}$ & $\begin{array}{c}\text { Total } \\
\text { Construction } \\
\text { Costs }(\$ S)\end{array}$ \\
\hline 400 & $10 \times 10 \times 2$ & $16 \times 16$ & 10,000 & $2,560,000$ & $4,040,000$ & 1138 \\
600 & $20 \times 15 \times 2$ & $26 \times 21$ & 10,000 & $5,460,000$ & $7,655,000$ & 2156 \\
800 & $20 \times 20 \times 2$ & $26 \times 26$ & 10,000 & $6,760,000$ & $9,720,000$ & 2738 \\
1000 & $25 \times 20 \times 2$ & $31 \times 26$ & 10,000 & $8,060,000$ & $11,835,000$ & 3334 \\
\hline
\end{tabular}

pond and the pond liner (PVC) used in this study for all the four alternative pond capacities. All these costs are calculated based on a one-hectare piece of land for crop cultivation and irrigation. The costs are presented in Ugandan Currency, UGX. ( $\$ 1$ US is equivalent to 3550 UGX).

Table 4 presents the capital, maintenance and operational costs for the water lifting techniques for the four-different water lifting systems which are analyzed in this study.

The results in Figure 7 represents the simulated yields of supplemental irrigation using different pond capacities. The study used data for the past ten years to represent the hydrological conditions in the region. The system with the least value of yields is the rain-fed, closely followed by the supplemental irrigation system of $400,600,800$ and $1000 \mathrm{~m}^{3}$ respectively. These results are used to calculate the Average Annual Growth. There was a yield increase of between 25\% to $50 \%$ in case of supplemental irrigation compared to rain-fed system alone. This increase is mainly attributed from the four dry years that were analyzed. These four seasons were previously considered as dry years by the Ugandan government since they had frequent dry spells and droughts that led to the failure of almost all the crops nationwide [48]. 
Historical Yields for Different Pond Capacities

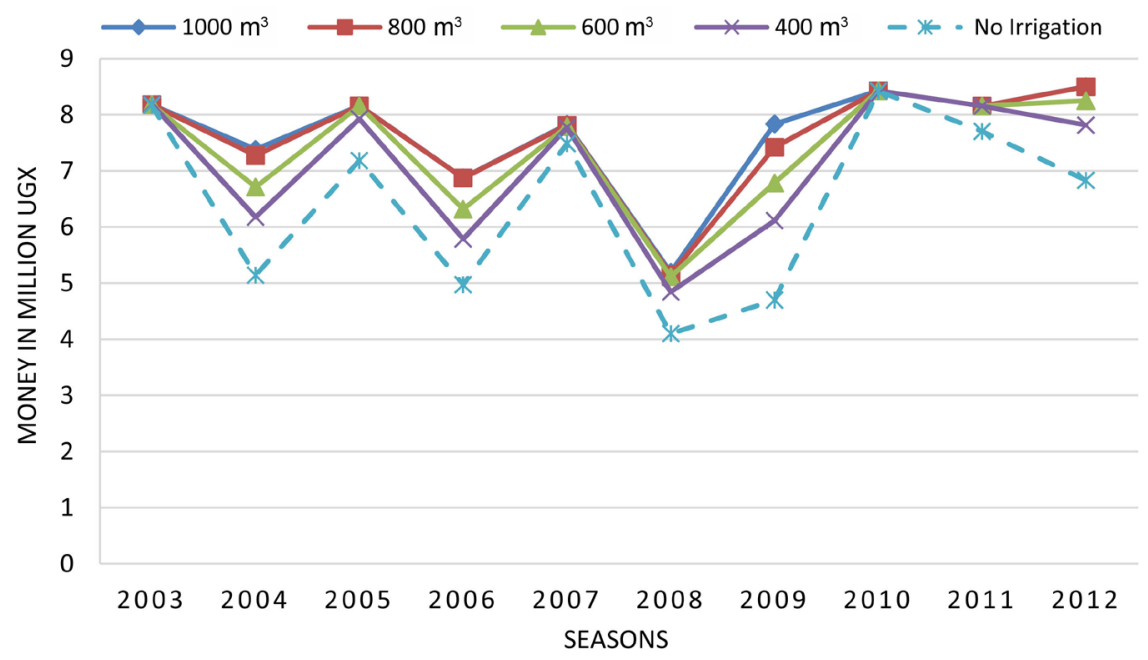

Figure 7. Historical seasonal monetary yields.

Table 4. Summarized costs for the water lifting techniques for supplemental irrigation.

\begin{tabular}{ccccc}
\hline $\begin{array}{c}\text { Water-Lifting } \\
\text { Technique }\end{array}$ & $\begin{array}{c}\text { Flow rate } \\
\left(\mathrm{m}^{3} / \mathrm{h}\right)\end{array}$ & $\begin{array}{c}\text { Purchasing } \\
\text { Price }(U G X)\end{array}$ & $\begin{array}{c}\text { Annual Operation costs of the } \\
\text { pump and maintenance of pond }(U G X)\end{array}$ & $\begin{array}{c}\text { Life span } \\
\text { in years }\end{array}$ \\
\hline Rope and Bucket & 2 & 120,000 & $5,040,000(\$ 1420)$ & 1 \\
Treadle Pump & 6 & 720,500 & $730,000(\$ 205)$ & 6 \\
Solar Pump & 8 & $5,060,000$ & $260,000(\$ 73)$ & 10 \\
Diesel Pump & 15 & $2,090,000$ & $452,000(\$ 127)$ & 20 \\
\hline
\end{tabular}

This study findings conform to the few scientific studies that have been conducted regarding supplemental irrigation elsewhere in the world [49]. The authors reported about $60 \%$ increment in crop yields compared to rain-fed system. Other researchers who found relatively similar results when they experimented supplemental irrigation on other crops [5] [50] reported that dry seasons supported with supplemental irrigation had up-to $74 \%$ increase in yields. With this insufficiency in research concerning supplemental irrigation in mainly Sub-Saharan Africa, this prompted us to generate an economic analysis to investigate the feasibility of the proposed system. The calculated Annual Average growth for Irrigated agriculture is $2.86 \%$. This value is used to forecast the future yield values for a period of 17 years. The period of forecast is selected to be 17 years because it was found most suitable for all the water lifting alternatives used in this study regarding their life span. The forecast period is from the current year 2017 till 2034. Figure 8 however, represents data for this projection since there was no data records from 2012 till 2017 which is the baseline year for the forecast, this study made forecasts for the missing years till 2017 to have a baseline from the current year (2017). The following equations are used to calculate the Annual average growth yield and the forecasted yield. Since there is a significant inflation of $5.50 \%$ in Uganda, this rate is also taken into consideration to increase the accuracy of the results [51]. 


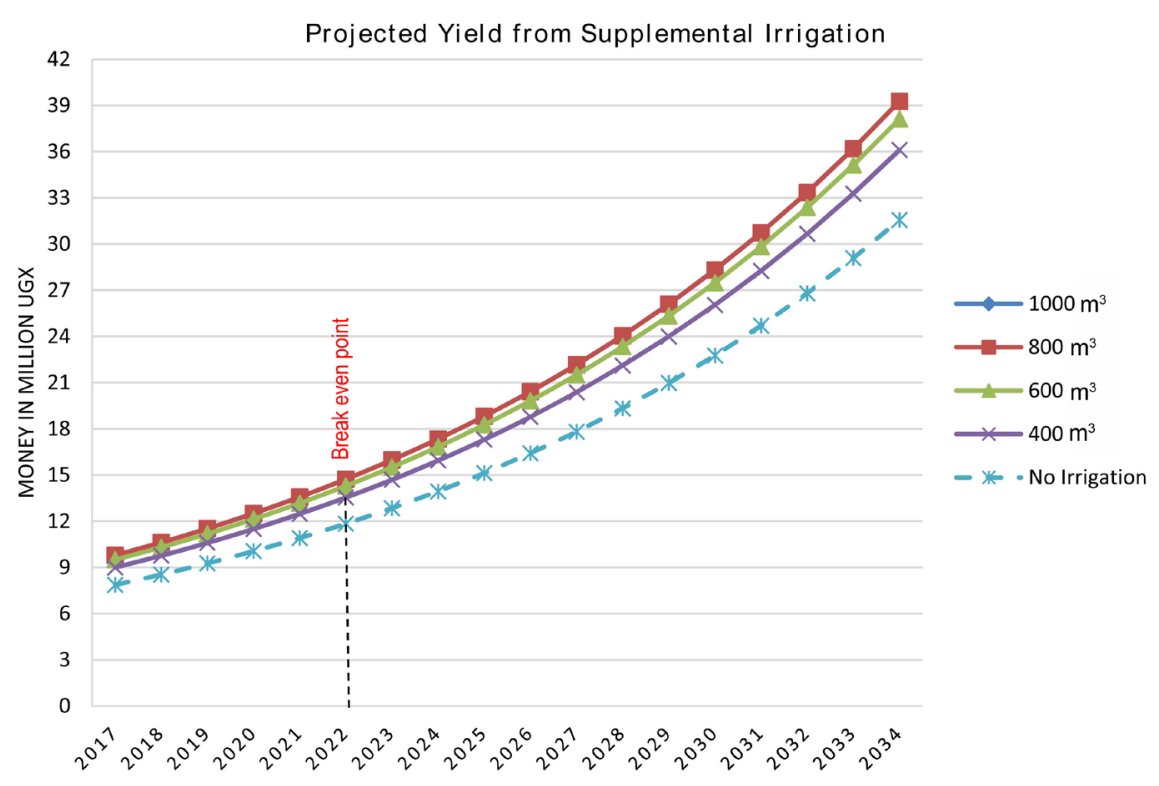

Figure 8. Forecasted monetary yield value.

$$
\begin{aligned}
& \text { Average Annual Yield growth } \\
& =\frac{\text { Yield in current year }- \text { Yield in previos year }}{\text { Yield in previous year }} \times 100
\end{aligned}
$$

Forecasted yield value

$=$ Previous yield value $\times(1+$ Average annual yield $) \times(1+$ Inflation rate $)$

The values for these calculations are also presented in Ugandan currency $U G X$.

After the calculation of the yield forecast, the study further calculates the discounted cash flow (DFC) for the alternative systems. Using an interest rate of $10 \%$ [51], the Net Present Values (NPV) for pond capacities are also calculated to better estimate the profitability of the project if farmers adopt and willingly invest their money in such a supplemental scheme. A similar concept of Net Present Value (NPV) for the water lifting techniques is also calculated. This is also forecasted for 17 years from the present year 2017.

\subsection{Optimization of Supplemental Irrigation}

Having calculated the NPV for both the pond volumes and the water lifting techniques, in addition to the benefits from the supplemental irrigation, the most profitable duo system i.e. (the optimum pond volume and the most profitable lifting technique) is estimated. Figure 9 presents the most profitable supplemental irrigation for maize production in rain-fed systems. With the complete analysis of the economic benefits, the study finds that the most profitable system is the $800 \mathrm{~m}^{3}$ pond along with the diesel pumping technique using furrow irrigation. Due to the high number of workers required for the rope and bucket system to carry out the manual irrigation activities, it makes the system unfeasible 
Optimization of Supplemental irrigation

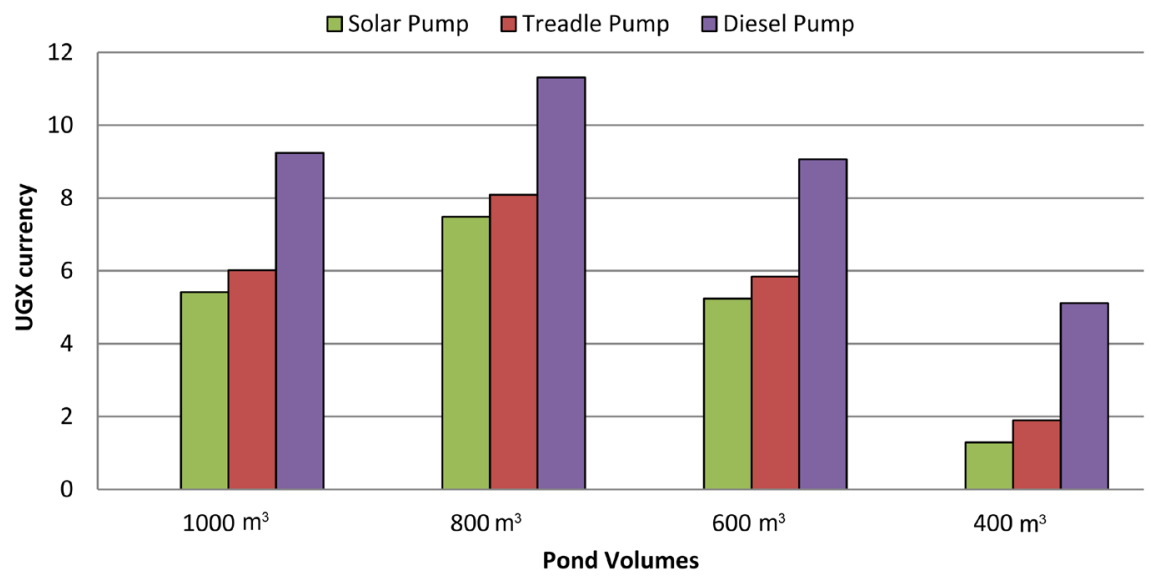

Figure 9. Profitability of different pond sizes with different lifting techniques.

to implement on such a large scale. For this reason, it was excluded in the economic analysis.

The treadle pump gives very good profits even more than the solar pump though still low compared to the diesel pump. Concerning the solar pump, its profitability is lower compared to the treadle and the diesel pump. This might be because of its high purchasing costs since it is still a new technology despite of being environmentally friendly. The diesel pump presents the highest profits amongst others maybe because of its durability (very long-life span if maintained well). However, it poses a great challenge to the environment since the system uses fossil fuels to operate. Furthermore, the study calculated the payback period or the break-even period for the selected system ( $800 \mathrm{~m}^{3} /$ diesel pump) to be 6.02 years. This period is calculated basing on both total costs and total revenue from the forecasted yields i.e. the point at which total costs will be equal to the total revenue and the farmer will start to earn profits out of his investment.

\section{Conclusions}

The study presents a simple sustainable economic solution for the problem of crop failures due to short droughts and dry spells during the crop growing seasons. As one of the most important staple foods in almost all regions of Sub-Saharan Africa, the production of Maize has greatly decreased due to water shortage. So, this study proposes that a farmer can sacrifice $5 \%$ of his cropland to construct a micro storage system that can collect surface runoff and use it primarily during the critical growth stages for a maize crop. The study suggests developing an earthen lined pond of $800 \mathrm{~m}^{3}$ by volume along with a diesel pump to protect a one-hectare piece of cropland from intra-seasonal droughts.

Such a relatively cheap technology could greatly facilitate the up scaling of rainwater harvesting for small scale irrigation. This would thus boost farmers' yields and prevent crop loss due to insufficient or unevenly distributed rainfall. The study makes use of the crop water productivity model (AquaCrop) to esti- 
mate and predict the yield of supplemental irrigation using data from the study area in Eastern Uganda. The model is found very useful in relating climatic data more particularly rainfall patterns to crop yields. Such a model can be utilized for other locations anywhere in the world to estimate crop yields in relation to rainfall patterns for that specific location.

Lastly, additional research in the area of supplemental irrigation is very vital due to the fact that there are only few published data. In this study, we considered a few assumptions to generate the study's results. These results are based on the data from the study area, so the results are area specific. The crop under investigation is a maize crop which has different moisture critical stages, different water needs and as well different growth patterns compared to other crops. All these differences are possible areas of research which needs to be covered. The study gives no details of the pond balancing for the whole year; it only focused on irrigation in the moisture critical period during the growing season.

\section{Conflicts of Interest}

The authors declare no conflicts of interest regarding the publication of this paper.

\section{References}

[1] World Bank (2017) Water in Agriculture. Understanding Poverty. http://www.worldbank.org/en/topic/water-in-agriculture

[2] Frone, D.-F. and Frone, S. (2015) The Importance of Water Security for Sustainable Development in the Romanian Agri-Food Sector. Agriculture and Agricultural Science Procedia, 6, 674-681. https://doi.org/10.1016/j.aaspro.2015.08.120

[3] Katko, T.S. and Hukka, J.J. (2015) Social and Economic Importance of Water Services in the Built Environment: Need for More Structured Thinking. Procedia Economics and Finance, 21, 217-223. https://doi.org/10.1016/S2212-5671(15)00170-7

[4] FAO (2009) The Challenge. In: How to Feed the World 2050, 4.

[5] Pandey, P.K., van der Zaag, P., Soupir, M.L. and Singh, V.P. (2013) A New Model for Simulating Supplemental Irrigation and the Hydro-Economic Potential of a Rainwater Harvesting System in Humid Subtropical Climates. Water Resources Management, 27, 3145-3164. https://doi.org/10.1007/s11269-013-0340-1

[6] Rockström, J., et al. (2010) Managing Water in Rainfed Agriculture-The Need for a Paradigm Shift. Agricultural Water Management, 97, 543-550.

https://doi.org/10.1016/j.agwat.2009.09.009

[7] Falkenmark, M., Fox, P., Persson, G. and Rockström, J. (2001) Water Harvesting for Upgrading of Rainfed Agriculture Problem Analysis and Research Needs. Stockholm.

[8] Conway, D. (2005) From Headwater Tributaries to International River: Observing and Adapting to Climate Variability and Change in the Nile Basin. Global Environmental Change.

[9] Ngigi, S.N. (2003) What Is the Limit of Up-Scaling Rainwater Harvesting in a River Basin? Physics and Chemistry of the Earth, 28, 943-956.

https://doi.org/10.1016/j.pce.2003.08.015 
[10] Freitas, A. (2013) (Rep.). European Union Institute for Security Studies (EUISS). http://www.jstor.org/stable/resrep06915

[11] Frenken, K. (2005) Irrigation in Africa in Figures: AQUASTAT Survey, 2005. Food and Agriculture Organization of the United Nations.

[12] Helena, S., Lucia, S., Town, G. and Asia, S. (2014) Urban and Rural Areas 2014. Population Division, Department of Economic and Social Affairs, United Nations.

[13] Yohannes, O. and Yohannes, K. (2013) Turmoil in the Nile River Basin: Back to the Future? Journal of Asian and African Studies. https://doi.org/10.1177/0021909612447175

[14] GoU (2010) National Development Plan (2010/11-2014/15). Development, April $2010,417$.

[15] MAAIF (2010) Agriculture for Food and Income Security. Kampala.

[16] Mugasha, C. (2014) Uganda: Farmers Want to Turn to Irrigation as Drought Drags on.

http://nepadwatercoe.org/uganda-farmers-want-to-turn-to-irrigation-as-drought-d rags-on/

[17] McCartney, M. and Smakhtin, V. (2010) Water Storage in an Era of Climate Change: Addressing the Challenge of Increasing Rainfall Variability. Blue Paper. https://doi.org/10.5337/2010.012

[18] Fischer, G., et al. (2012) Global Agro-Ecological Zones (GAEZ): Model Documentation. 1-179.

[19] Kannan, N., Senthivel, T., Rayar, A.J. and Frank, M. (2010) Investigating Water Availability for Introducing an Additional Crop Yield in Dry Season on Hill Land at Rubirizi, Rwanda. Agricultural Water Management, 97, 623-634.

[20] Nangia, V. and Oweis, T. (2016) Supplemental Irrigation: A Promising Climate-Resilience Practice for Sustainable Dryland Agriculture. In: Farooq, M. and Siddique, K., Eds., Innovations in Dryland Agriculture, Springer, Cham, 549-564.

[21] Oweis, T. and Hachum, A. (2012) Supplemental Irrigation-A Highly Efficient Water-Use Practice. Aleppo.

[22] Pandey, P.K., Panda, S.N. and Panigrahi, B. (2006) Sizing On-Farm Reservoirs for Crop-Fish Integration in Rainfed Farming Systems in Eastern India. Biosystems Engineering, 93, 475-489. https://doi.org/10.1016/j.biosystemseng.2006.01.009

[23] McSweeney, C., New, M. and Lizcano, G. (2006) UNDP Climate Change Country Profiles.

[24] Kansiime, M.K., Wambugu, S.K. and Shisanya, C.A. (2013) Perceived and Actual Rainfall Trends and Variability in Eastern Uganda: Implications for Community Preparedness and Response. Journal of Natural Sciences Research, 3, 2225-2921.

[25] Geerts, S. and Raes, D. (2009) Deficit Irrigation as an On-Farm Strategy to Maximize Crop Water Productivity in Dry Areas. Agricultural Water Management, 96, 1275-1284. https://doi.org/10.1016/j.agwat.2009.04.009

[26] Mango, N., Makate, C., Tamene, L., Powell, M. and Ndengu, G. (2018) Adoption of Small-Scale Irrigation Farming as a Climate-Smart Agriculture Practice and Its Influence on Household Income in the Chinyanja Triangle, Southern Africa. 1-32.

[27] Vohland, K. and Barry, B. (2009) A Review of in Situ Rainwater Harvesting (RWH) Practices Modifying Landscape Functions in African Drylands. Agriculture, Ecosystems and Environment, 131, 119-127. https://doi.org/10.1016/j.agee.2009.01.010

[28] GoU and UNFPA (2009) The State of Uganda Population Report 2009: Addressing 
the Effects of Climate Change on Migration. Development, 1-78.

[29] Ocowunb, C. (2009) Uganda: Long Droughts, Food Shortage Hit Country as Victims Cry out for Help. http://allafrica.com/stories/200907090729.html

[30] Majaliwa, J.G.M., et al. (2015) Characterization of Historical Seasonal and Annual Rainfall and Temperature Trends in Selected Climatological Homogenous Rainfall Zones of Uganda. Global Journal of Science Frontier Research, 15.

[31] NEMA (2007) State of the Environment Report for Uganda. Kampala.

[32] Stark, J. (2011) Climate Change and Conflict in Uganda: The Cattle Corridor and Karamoja. Karamoja.

[33] Mubiru, D.N., Komutunga, E., Agona, A., Apok, A., Ngara, T. and Mubiru, D. (2012) Characterising Agrometeorological Climate Risks and Uncertainties: Crop Production in Uganda. South African Journal of Science, 108, 108-118.

[34] Atta-Krah, K., Sanginga, N., Tripathi, B.R. and Psychas, P.J. (1992) The Afneta Alley Farming Training Manual. Alley Farming Network for Tropical Africa.

[35] Chenery, E.M. (1960) An Introduction to the Soils of the Uganda Protectorate. Kawanda Research Station, Kampala.

[36] Kaaya, A.K., Msanya, B.M. and Mrervla, J.P. (1994) Soils and Land Evaluation of Part of the Sokoine University of Agriculture Farm (Tanzania) for Some Crops under Rainfed Conditions. African Study Monographs, 15, 97-117.

[37] Driessen, P. (2001) Lecture Notes on the Major Soils of the World. FAO, Rome.

[38] Okalebo, J., Gathua, K. and Woomer, P. (2002) Laboratory Methods of Soil and Plant Analysis: A Working Manual. 2nd Edition, Sacred African Publishers, Nairobi.

[39] Subedi, P. and Shrestha, J. (2015) Improving Soil Fertility through Azolla Application in Low Land Rice: A Review. Azarian Journal of Agriculture, 2, 35-39.

[40] Van Hove, C., Baillonville, T.D.W., Diara, H.F., Godard, P., Kodomi, Y.M. and Sanginga, N. (1987) Azolla Collection and Selection.

[41] Imbahale, S.S., Mweresa, C.K., Takken, W. and Mukabana, W.R. (2011) Development of Environmental Tools for Anopheline Larval Control. Parasites and Vectors, 4, 1-10. https://doi.org/10.1186/1756-3305-4-130

[42] Mahapatra, B.S. and Sharma, G.L. (1989) Integrated Management of Sesbania, Azolla and Urea Nitrogen in Lowland Rice under a Rice-Wheat Cropping System. The Journal of Agricultural Science, 113, 203. https://doi.org/10.1017/S0021859600086779

[43] Ashraf, H., Matto, F.A., Ganai, A.M., Reshi, I.M. and Sheikh, F.A. (2015) Effect of Replacement of Mustard Oil Cake with Azolla (Azolla pinnata) Meal on Growth Performance of Broilers and Economics of Feeding under Temperate Conditions. Indian Journal of Animal Nutrition, 32, 325-328.

[44] Singh, B., Meena, G., Meena, K., Meena, R., Singh, B. and Indoria Krishi Vigyan Kendra, D. (2017) Effect of a Wonder Herb Azolla on Buffaloes Milk Yield. International Journal of Current Microbiology and Applied Sciences, 6, 1059-1066. https://doi.org/10.20546/ijcmas.2017.611.124

[45] Pandey, P.K., Soupir, M.L., Singh, V.P., Panda, S.N. and Pandey, V. (2011) Modeling Rainwater Storage in Distributed Reservoir Systems in Humid Subtropical and Tropical Savannah Regions. Water Resources Management, 25, 3091-3111. https://doi.org/10.1007/s11269-011-9847-5

[46] FAO (2017) Final Evaluation of the Global Climate Change Alliance (GCCA). 
Agricultural Adaptation to Climate Change Project.

[47] Brouwer, C. and Heibloem, M. (1986) Chapter 2: Crop Water Needs. http://www.fao.org/docrep/s2022e/s2022e02.htm

[48] MEV (2007) Climate Change: Uganda National Adaptation Programmes of Action (NAPA). Ministry of Water and Environment (MEV), Kampala, 73.

[49] Rockström, J. and Barron, J. (2007) Water Productivity in Rainfed Systems: Overview of Challenges and Analysis of Opportunities in Water Scarcity Prone Savannahs. Irrigation Science, 25, 299-311. https://doi.org/10.1007/s00271-007-0062-3

[50] Barron, J., Rockström, J., Gichuki, F. and Hatibu, N. (2003) Dry Spell Analysis and Maize Yields for Two Semi-Arid Locations in East Africa. Agricultural and Forest Meteorology, 117, 23-37. https://doi.org/10.1016/S0168-1923(03)00037-6

[51] Trading Economics (2017) Uganda Inflation Rate-Forecast. https://tradingeconomics.com/uganda/inflation-cpi/forecast 